НАУКОВИЙ ВІСНИК

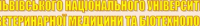

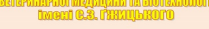

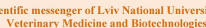

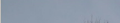

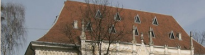
211 IIIMU

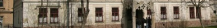

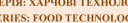
Том 23 № 95 2021

\section{Науковий вісник Яьвівського національного університету ветеринарної медицини та біотехнологій імені С.3. Гжицького. Серія: Харчові технології}

\author{
Scientific Messenger of Lviv National University
} of Veterinary Medicine and Biotechnologies.

Series: Food Technologies https://nvlvet.com.ua/index.php/food

UDC 664.65:633.4

\title{
Use of topinambur in technology of flour products
}

\author{
G. P. Khomych ${ }^{1}$, N. I. Tkach ${ }^{1}$, Y. G. Nakonechna ${ }^{1}$, O. V. Nesterenko ${ }^{1}$, N. M. Prior ${ }^{2}$ \\ ${ }^{1}$ Poltava University of Economics and Trade, Poltava, Ukraine \\ ${ }^{2}$ Zhytomyr Cooperative College of Business and Law, Zhytomyr, Ukraine
}

Article info

Received 07.01.2021

Received in revised form 10.02.2021

Accepted 11.02.2021

Poltava University of Economics and Trade, Kovalya Str., 3,

Poltava, 36014, Ukraine. Tel.: +38-053-250-02-22 E-mail: can@puet.edu.ua

Zhytomyr Cooperative College of Business and Law, Kyivska Str., 82 , Zhytomyr, 10012, Ukraine. Tel.: +38-041-243-40-11 E-mail: zhitocol@ukr.net
Khomych, G. P., Tkach, N. I., Nakonechna, Y. G., Nesterenko, O. V., \& Prior, N. M. (2021). Use of topinambur in technology of flour products. Scientific Messenger of Lviv National University of Veterinary Medicine and Biotechnologies. Series: Food Technologies, 23(95), $13-19$. doi: $10.32718 /$ nvlvet-f9503

The article considers the use of Jerusalem artichoke processing products in technology flour yeast products. In terms of productivity, Jerusalem artichokes significantly exceed potatoes, sugar beets, corn and other crops of intensive type, but grow it on small area mainly for fodder purposes. Recently, in the food industry is observed reorientation to the production of products with new qualities, aimed at improving the situation health and disease prevention. Jerusalem artichoke is a unique raw material that can increase the biological value of finished products. Useful properties of Jerusalem artichoke are used to strengthen the immune system, reduce the risk of heart attack and stroke, eliminate salt deposits in the joints, in the therapeutic diet for diabetes. However, its limited use in the processing industry is due to the rapid enzymatic darkening of Jerusalem artichoke tubers during processing. Given the specific properties of Jerusalem artichoke, it is advisable to investigate the enzymatic darkening of Jerusalem artichoke tubers during processing by determining the activity of the enzyme polyphenol oxidase and the use of Jerusalem artichoke puree in the technology of yeast dough. Analysis of tubers and Jerusalem artichoke puree was performed by organoleptic and physicochemical indicators. The quality of finished products was controlled by organoleptic, physicochemical and structural and mechanical indicators, among which special attention was paid to indicators acidity, humidity, porosity, shape stability. The activity of the enzyme in whole and crushed Jerusalem artichoke tubers and its effect on the activity of the enzyme pre-blanching in water for 10 minutes It is determined that when blanching is a partial inactivation of the enzyme polyphenol oxidase, which prevents darkening of raw materials during grinding. The effect of adding Jerusalem artichoke puree in the amount of 10, 15 and $20 \%$ was studied on gluten of wheat flour. The partial replacement of wheat flour in mashed Jerusalem artichoke leads not only to a decrease in the amount of gluten, but also to a change in its quality. The gluten becomes more elastic, the extensibility decreases, and with the addition of $20 \%$ puree gluten is torn. It is determined that the duration of fermentation of dough samples varies depending on the amount introduced Jerusalem artichoke puree. With increasing percentage of Jerusalem artichoke puree in the dough recipe, the duration of dough fermentation is reduced by $6.25 \ldots 8.75 \%$. The addition of puree had a positive effect Jerusalem artichoke to increase the yield of the finished product by $5.20 \ldots 26.34 \%$. Research of the main quality indicators of experimental samples confirm that according to the set of indicators, the optimal sample is $10 \%$ of Jerusalem artichoke puree, which makes it possible to recommend it for the production of yeast bakery products of high biological value.

Key words: Jerusalem artichoke puree, bakery products, darkening, polyphenol oxidase, physicochemical, structural and mechanical parameters, yield, biological value.

\section{Використання топінамбуру у технології борошняних виробів}

\author{
Г. П. Хомич ${ }^{1}$, Н. І. Ткач ${ }^{1}$, Ю. Г. Наконечна ${ }^{1}$, О. В. Нестеренко ${ }^{1}$, Н. М. Пріор ${ }^{2}$ \\ ${ }^{1}$ Полтавський університет економіки і торгівлі, м. Полтава, Україна \\ ${ }^{2}$ Житомирський кооперативний коледж бізнесу та права, м. Житомир, Украӥна
}


В статті розглянуто питання використання продуктів переробки топінамбуру в технології борошняних дріжджсвих виробів. За своєю продуктивністю топінамбур значно перевищує картоплю, иукрові буряки, кукурудзу та інші культури інтенсивного типу, але вирошують його на невеликих площах переважно для кормових иілей. Останнім часом у харчовій промисловості спостерігається переорієнтація на виробництво продукиї з новими якостями, направленими на покращення здоров'я та попередження виникнення захворювань. Топінамбур є унікальною сировиною, яка здатна підвишити біологічну иінність готової продукиії. Корисні властивості топінамбура застосовуються для зміцнення імунітету, зниження ризику інфаркту та інсульту, усунення сольових відкладень у суглобах, у лікувальному харчуванні при иукровому діабеті. Однак, обмежене його використання в переробній промисловості пов 'язане з швидким ферментативним потемнінням бульб топінамбуру при переробці. 3 огляду на специфічні властивості топінамбуру дочільно: дослідити протікання ферментативного потемніння бульб топінамбуру в процесі переробки шляхом визначення активності ферменту поліфенолоксидази і використання пюре топінамбуру в технології дріжджового здобного тіста. Аналіз бульб та пюре з топінамбуру проводили за органолептичними $і$ фізико-хімічними показниками. Якість готових виробів контролювали за органолептичними, фізико-хімічними та структурно-механічними показниками, серед яких особливу увагу приділили показникам кислотності, вологості, пористості, формостійкості. Досліджено активність ферменту в изілх і подрібнених бульбах топінамбуру і вплив на активність ферменту попереднього бланшування у воді протягом 10 хв. Визначено, ияо при бланшуванні відбувається часткова інактивачія ферменту поліфенолоксидази, яка запобігає потемнінню сировини при подрібненні. Досліджено вплив додавання пюре топінамбуру у кількості 10, 15 i 20 \% на клейковину пшеничного борошна і показано, щзо часткова заміна пшеничного борошна на пюре з топінамбуру приводить не тільки до зменшення кількості клейковини, але й до зміни ї̈ якості, клейковина стає більш пружною, розтяжність зменшується, а при додаванні 20\% пюре клейковина розривається. Визначено, шзо тривалість бродіння зразків тіста змінюється в залежності від кількості внесеного пюре топінамбуру. При збільшенні відсотку пюре топінамбура в рецептурі тіста, скорочується тривалість бродіння тіста на 6,25...8,75 \%. Позитивно вилинуло додавання пюре топінамбуру на зростання виходу готового продукту на 5,20...26,34 \%. Дослідження основних показників якості експериментальних зразків підтверджують, щзо за комплексом показників, оптимальним є зразок з $10 \%$ пюре топінамбуру, ияо дає можливість рекомендувати його для виробництва здобного булочного виробу підвищеної біологічної иінності.

Ключові слова: пюре топінамбуру, булочні вироби, потемніння, поліфенолоксидаза, фізико-хімічні, структурно-механічні показники, вихід, біологічна цінність.

\section{Вступ}

Сучасна харчова промисловість України потребує впровадження новостворених або удосконалених інноваційних технологій і випуску на їхній основі харчових продуктів із новими споживними та функціональними властивостями. Саме на таких технологіях і нових продуктах грунтується можливість вирішення пріоритетного на сьогодні завдання - створення в Україні індустрії оздоровчих продуктів 3 метою поліпшення стану здоров'я споживачів, підвищення якості життя, збереження генофонду нації (Pahoms'ka, 2019).

У сфері виробництва нових харчових продуктів зараз позиціонуються наступні категорії: оздоровчі, функціональні, збагачені, пробіотичні, органічні продукти (Drobot, 2011; Dorohovych et al., 2011). Із зазначених категорій продуктів найбільш популярними на світовому ринку є: органічні продукти, що характеризуються поліпшеною якістю та безпечністю, відсутністю ризику забруднення ксенобіотиками, збереженням корисних властивостей сировини на етапі виробництва продукції; фізіологічно функціональні продукти, що характеризуються позитивними змінами показників якості в результаті модифікації складу нутрієнтів згідно з парадигмою нової концепції здорового харчування (Bortnichuk, 2015; Vlasenko, \& Kryvoruk, 2017).

Одним зі шляхів вирішення поставленої проблеми $\epsilon$ пошук поліпшувачів для підвищення якості та скорочення термінів приготування дріжджових виробів серед нетрадиційної рослинної сировини. Цій проблемі було присвячено багато уваги провідними вітчизняними вченими, які досягли значних успіхів у впровадженні новітніх технологій у практику створення продуктів 3 підвищеною біологічною цінністю (Dorohovych et al., 2011; Pahoms'ka, 2019).

В сучасних умовах традиційне харчування не забезпечує надходження до організму всіх необхідних харчових та мінорних активних компонентів, необхідних для його нормального функціонування. Останнім часом поряд з захворюваннями серцево-судинної системи значних масштабів набуває захворювання населення цукровим діабетом, який є основною медико-соціальною проблемою сучасного суспільства через значне розповсюдження захворювання та розвиток ускладнень внаслідок перебігу хвороби. Чисельність хворих на цукровий діабет щороку збільшується на $6 . .10 \%$ (Rak, 2019).

Виходячи 3 цього, перспективним напрямком $\epsilon$ створення продуктів підвищеної біологічної цінності завдяки використанню нетрадиційної рослинної сировини, що містить поживні компоненти, зокрема, особливої уваги заслуговують борошняні вироби, які $\epsilon$ продуктами щоденного вжитку. Відомо, що одним із важливих полісахаридів, що володіє пребіотичними властивостями, $є$ інулін. Цінність інуліну в позитивному впливові на обмін речовин в організмі людини, зокрема, його наявність покращує обмін ліпідів, що дозволяє знизити ризик серцево-судинних захворювань, сприяє нормальному функціонуванню шлунково-кишкового тракту, справляе імуномодулюючу дію тощо. Джерелами інуліну може бути рослинна сировина, така як топінамбур (Helianthus tuberosus), якон (Polymnia sonchifolia), кульбаба (Taraxacum officinale), лопух (Arctium lappa), цикорій (Cichorium intybus), скорцонера (Scorzonera hispanica), жоржина (Dahlia pinnata) (Korkach et al., 2009).

Топінамбур - цінна сировини, що містить в своєму складі, окрім інуліну, аскорбінову кислоту, вітамін $\mathrm{B}_{1}$, $\mathrm{B}_{2}, \mathrm{E}$, холін, білки жири пектинові, дубильні речовини, значну кількість макро- та мікроелементів, мінеральні речовини (калій, кальцій, магній, фосфор, залі3 та ін.) (Apolinário et al., 2014; Liu et al., 2015; Ahmed \& Rashid, 2019).

Проводилися дослідження використання пюре топінамбуру в технології отримання соусів (Homych et al., 2016). Розроблена технологія ферментованих ку- 
пажованих соків на основі топінамбура (Stankevych et al., 2011).

3 огляду на антитоксичні властивості топінамбуру та продуктів його переробки, здатність поліпшувати функціонування внутрішніх органів за рахунок тонізуючого впливу, активізувати ферментативні процеси травного тракту доцільно дослідити можливість його використання при виробництві борошняних дріжджових виробів. Метою роботи є дослідження впливу пюре топінамбуру на процес тістоутворення, показники якості борошняних виробів та удосконалення технології виробництва.

Завданням роботи було визначити органолептичні та фізико-хімічні показники вихідної сировини, вплив попередньої обробки бульб топінамбуру на активність ферментативного потемніння сировини, дослідити вплив пюре $з$ топінамбуру на процес тістоутворення i бродіння, вплив пюре топінамбуру на органолептичні, фізико-хімічні та структурно-механічні показники готових виробів.

\section{Матеріал і методи досліджень}

Для досліджень використовували наступні матеріали: топінамбур свіжий осіннього збору в Полтавській області, який відповідає вимогам ДСТУ 8046:2015 “Топінамбур (земляна груша) свіжий”; борошно пшеничне в/г за ГСТУ 46.004-99 “Борошно пшеничне. Технічні умови”; вироби булочні здобні за ДСТУ-П 4585:2006 "Вироби хлібобулочні здобні”.

Експериментальні дослідження проводили з використанням стандартних загальноприйнятих хімічних, фізикохімічних, біохімічних методів дослідження якості сировини і готових продуктів з використанням сучасних приладів і обладнання, комп'ютерних технологій. Активність поліфенолоксидази визначали колориметричним методом, що базується на вимірюванні активності ферменту за швидкістю утворення синьо-фіолетового забарвлення окисленого сірчанокислого діетилпарафенілен-діаміна.

\section{Результати та їх обговорення}

Найбільш зручними продуктами для корекції харчування $є$ хлібобулочні вироби. Аналіз хімічного складу та харчової цінності свідчить, що переважна більшість 3 них не відповідає вимогам нутріціології. Незбалансованість складу борошняних виробів пов'язана 3 високим вмістом жирів, вуглеводів та відносно низьким - білків, харчових волокон, ненасичених жирних кислот, вітамінів.

Джерелами цих волокон $є$ продукти рослинного походження, які в достатній кількості містять клітковину, геміцелюлозу, пектин та ін. До них відносять продукти переробки топінамбуру, в тому числі пюре 3 бульб топінамбуру.

Експериментальні дослідження були розпочаті 3 органолептичної оцінки бульб топінамбуру та аналізу їх хімічного складу. Сировину аналізували у стадії споживчої стиглості.

За органолептичною оцінкою топінамбур в розрізі має біле забарвлення, солодкий присмак та запах, притаманний даній сировині. Особливістю переробки топінамбуру, котра обмежує його використання при виробництві продуктів харчування, є швидке потемніння м'якоті, яке негативно впливає на якість готової продукції. Така особливість хімічного складу топінамбуру обмежує його використання у закладах ресторанного господарства і негативно впливає на якість готової продукції.

На початковому етапі обробки топінамбуру не виявляється візуально протікання ферментативної реакції, але через незначний проміжок часу очищена сировина починає темніти. Дослідження протікання ферментативної реакції визначали за активністю ферменту поліфенолоксидази. Враховуючи, що найбільш простим і зручним способом попередньої обробки для запобігання потемніння топінамбуру є бланшування, то досліджували вплив процесу бланшування на зміну активності ферменту поліфенолоксидази.

Визначали активність ферменту поліфенолоксидази в цілих бульбах та подрібненій сировині до і після теплової обробки (рис. 1). Сировину до теплової обробки витримували в цілому і подрібненому вигляді на повітрі протягом 10 хв. У випадку бланшування сировину піддавали обробці у воді при температурі $100{ }^{\circ} \mathrm{C}$ протягом 10 хв і також витримували на повітрі в цілому та подрібненому вигляді протягом 10 хв.

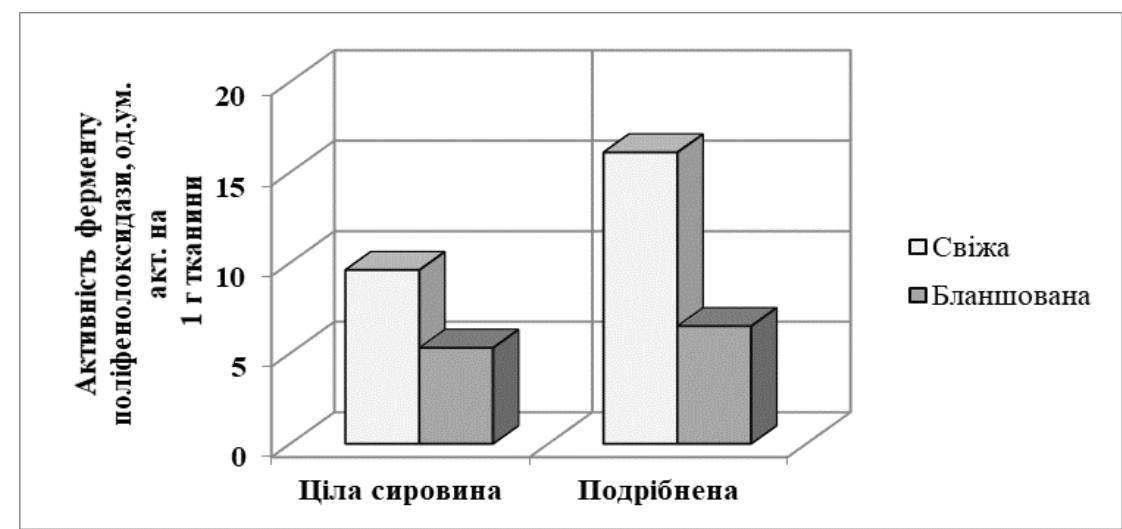

Рис. 1. Активність поліфенолоксидази в топінамбурі в залежності від виду обробки 
Дані експериментальних досліджень (рис. 1) показують, що активність ферменту поліфенолоксидази в зразках топінамбуру, які не піддавалися тепловій обробці досить високі і становлять 9,60 ум. од. акт. на 1 г тканини у свіжих плодах топінамбуру, а в процесі подрібнення активність поліфенолоксидази стрімко зростає і становить 16,10 ум. од. акт. Зовнішній вигляд подрібненого зразка свідчить про більш інтенсивне потемніння тканини, що пояснюється руйнуванням цілісності клітин, в стінках яких міститься фермент поліфенолоксидаза і активним впливом кисню повітря. Використання попередньої теплової обробки топінамбуру понижує активність ферменту поліфенолоксидази до 5,3 ум. од. акт. (цілий зразок) і 6,5 ум. од. акт. (подрібнений зразок), тобто активність ферменту зменшується в 1,8 рази у цілому зразку і у 2,5 рази - в подрібненому зразку.

Отже, проведені дослідження показують, що попередня теплова обробка бульб топінамбуру (бланшування у воді) викликає часткову інактивацію ферменту поліфенолоксидази і запобігає потемнінню сировини в процесі переробки.

Бульби топінамбуру промивали в проточній воді, бланшували в воді при температурі $100^{\circ} \mathrm{C}$ протягом 10 хв., охолоджували, очищали, протирали крізь сито діаметром 0,4...0,6 мм. Визначали показники якості в бульбах топінамбуру та отриманому пюре (табл. 1).

Таблиця 1

Фізико-хімічні показники свіжих бульб та пюре з топінамбуру

\begin{tabular}{cccccc}
\hline Назва & \multicolumn{3}{c}{ Масова частка, \% } & Вміст L-аскорбінової & $\mathrm{pH}$, \\
сировини & сухих речовин & титрованих кислот & пектинових речовин & киг/100г & од. $\mathrm{pH}$ \\
\cline { 2 - 5 } & 13,80 & 0,25 & 1,02 & 28,40 & - \\
Бульби топінамбура & 12,50 & 0,26 & 1,28 & 8,70 & 5,20 \\
Пюре топінамбура & & &
\end{tabular}

Результати проведених експериментальних досліджень (табл. 1) підтверджують, що топінамбур має низьку кислотність, високий вміст пектинових речовин, містить в своєму складі L-аскорбінову кислоту. Показники якості пюре топінамбуру мають незначне відхилення в порівнянні з сирими бульбами, що також свідчить про високий вміст в ньому біологічно активних речовин.

Для вивчення можливості використання пюре топінамбуру у технології виготовлення дріжджових булочних виробів, дослідили вплив його різних концентрацій на процеси тістоутворення і бродіння.

Одним із основних факторів, які обумовлюють си- лу борошна, є стан білково-протеїназного комплексу. Наявність пектинових речовин у досліджуваній рослинній сировині дозволяє впливати на стан білковопротеїназного комплексу борошна. Вплив на нього рослинних добавок оцінювали за кількістю і якістю клейковини.

Для дослідження впливу пюре на клейковину пшеничного борошна були виготовлені модельні зразки суміші пшеничного борошна і пюре топінамбуру у кількості 10, 15 і 20 \%. Відмивання клейковини проводилося за стандартною методикою, отримані показники якості клейковини наведені у табл. 2.

\section{Таблиця 2}

Вплив пюре топінамбуру на показники якості клейковини тіста

\begin{tabular}{lcccc}
\hline \multicolumn{1}{c}{ Показники } & \multirow{2}{*}{ Контроль } & \multicolumn{3}{c}{ Масова частка пюре топінамбуру, \% } \\
\cline { 3 - 5 } & & 10 & 15 & 20 \\
\hline Вихід сирої клейковини, \% & 34,12 & 25,44 & 21,92 \\
Пружність, од. пр. ІДК & 81,00 & 81,00 & 86,00 \\
Розтяжність, см & 15,50 & 17,00 & 84,00 & 15,50 \\
\hline
\end{tabular}

Отримані результати (табл. 2) свідчать, що часткова заміна пшеничного борошна на пюре 3 топінамбуру приводить не тільки до зменшення кількості клейковини, але й до зміни ії якості, клейковина стає більш пружною, розтяжність зменшується, а при додаванні $20 \%$ пюре клейковина розривається. Збільшення частки пюре впливає на колір клейковини i вона набуває сіруватого відтінку.

У якості контрольного зразка використовували рецептуру здобного виробу “Булочка “Дорожня”. Для визначення впливу рослинних добавок на властивості дріжджового тіста та хід технологічного процесу у тісто вносили пюре топінамбуру у кількості $10 \%$ (зразок 1), $15 \%$ (зразок 2) та $20 \%$ (зразок 3).

Найбільш складним і тривалим за часом при виготовленні дріжджових виробів є процес бродіння тіста. Одним із показників, за яким визначають ступінь готовності дріжджового тіста, є титрована кислотність. В процесі дозрівання дріжджового тіста поряд зі спиртовим протікає і молочнокисле бродіння, продуктами якого $\epsilon$ молочна та інші кислоти. Підвищення кислотності тіста прискорює процеси набухання та пептизації білкових речовин, що врешті решт впливає на структуру тіста, формування смаку та аромату готових виробів. Тому саме цей показник було обрано для визначення впливу пюре топінамбуру на дозрівання тіста і визначення його ступені готовності до випікання.

Кислотність тіста визначали після замісу до початку бродіння та наприкінці бродіння, коли об'єм тіста збільшився вдвічі. Результати досліджень впливу 
пюре топінамбуру на зміни титрованої кислотності наведені на рис. 2.

Аналіз результатів експериментальних досліджень (рис. 2) свідчить, що використання пюре топінамбуру вплинуло на зміни титрованої кислотності тіста до і після бродіння і демонструють стрімке зростання показника в дослідних зразках та досягнення значення
2,2 ${ }^{0} \mathrm{H}$ до бродіння у зразку 3 та максимального значення $2,8{ }^{0} \mathrm{H}$ після бродіння у зразках 2 та 3 . Кінцева кислотність зразка 1 на 12,5\% вище контрольного зразка, що свідчить про інтенсифікацію процесів бродіння у присутності пюре топінамбуру навіть у невеликій його кількості.

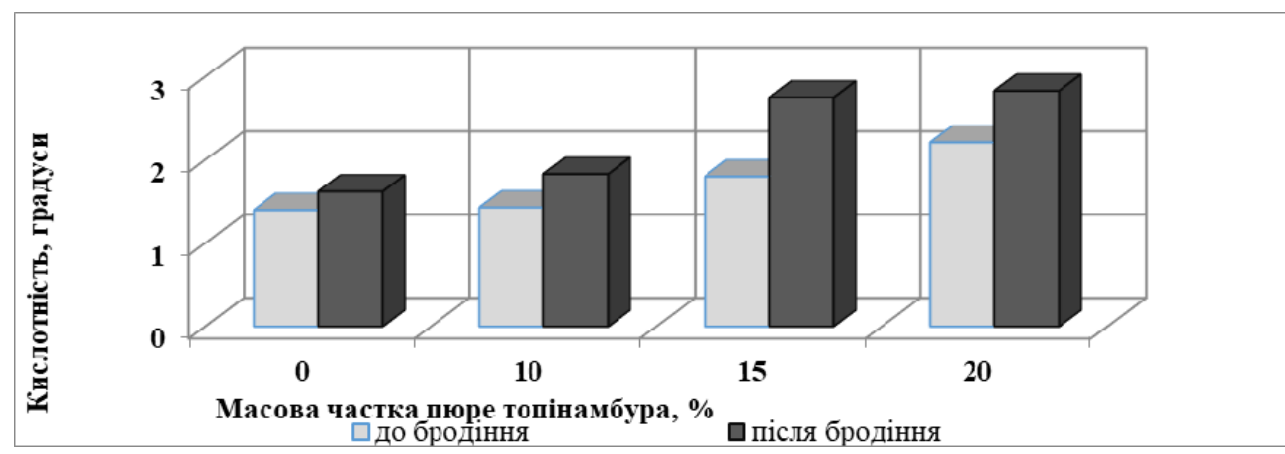

Рис. 2. Зміна титрованої кислотності в процесі бродіння в залежності від кількості пюре топінамбуру

Вплив пюре топінамбуру на тривалість бродіння зразків тіста наведено на рис. 3 .

Результати експериментальних досліджень (рис. 3) показують, що тривалість бродіння зразків тіста змінюється в залежності від кількості внесеного пюре топінамбуру. При збільшенні відсотку пюре топінамбура в рецептурі тіста, скорочується тривалість бро- діння, що можна пояснити підвищеним вмістом в пюре пектинових речовин, які за рахунок деполімеризації пектинових молекул до низькомолекулярних цукрів, разом 3 цукром створюють поживне середовище для життєдіяльності дріжджів. Відповідно отримані результати свідчать про скорочення тривалості бродіння тіста на $6,25 \ldots 8,75 \%$.

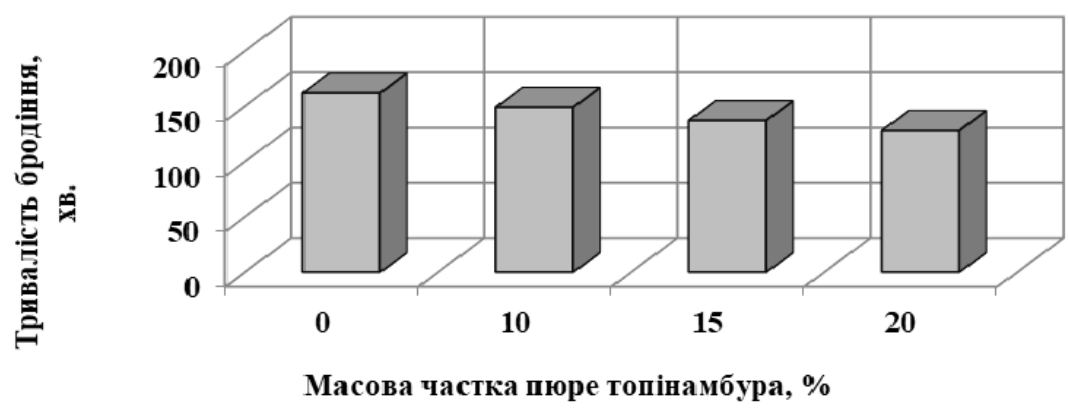

Рис. 3. Зміна тривалості бродіння в залежності від вмісту пюре топінамбуру

Після закінчення процесу бродіння з готового тіста були сформовані вироби масою 70 г. Збільшення кількості пюре в рецептурі виробу впливає на в'язкість тіста, зростання в'язкості спостерігається у зразку 3 (додавання 20 \% пюре). Сформовані вироби розстоювали 30 хв і випікали при температурі 230$240{ }^{\circ} \mathrm{C}$ протягом $10-12$ хв.

Показники якості готових виробів визначали за результатами органолептичної оцінки (рис. 4) та значеннями фізико-хімічних (табл. 3) і структурномеханічних (табл. 4) показників.

За органолептичною оцінкою (рис 4) найкращим було обрано зразок 1 з внесенням 10 \% пюре топінамбуру. Зразок відрізнявся приємним смаком та ароматом, еластичним м'якушем, привабливим зовнішнім виглядом. При внесенні 15 \% пюре (зразок 2) вироби мали віддалений присмак топінамбуру, а у випадку 20 \% пюре (зразок 3) відчувався характерний присмак топінамбуру.

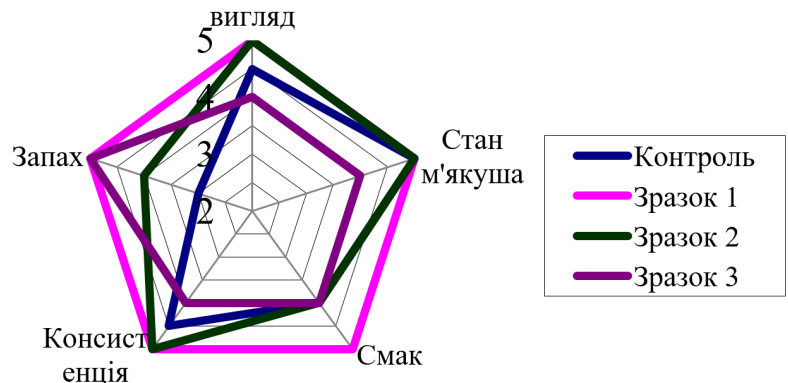

Рис. 4. Середня бальна оцінка експериментальних зразків булочних виробів

Збільшення частки пюре топінамбуру у рецептурі виробу підвищує солодкий смак дослідних зразків в порівнянні 3 контролем, що пояснюється впливом фруктози самого топінамбура.

Позитивно вплинуло додавання пюре топінамбуру на вихід готового продукту (рис. 5). 


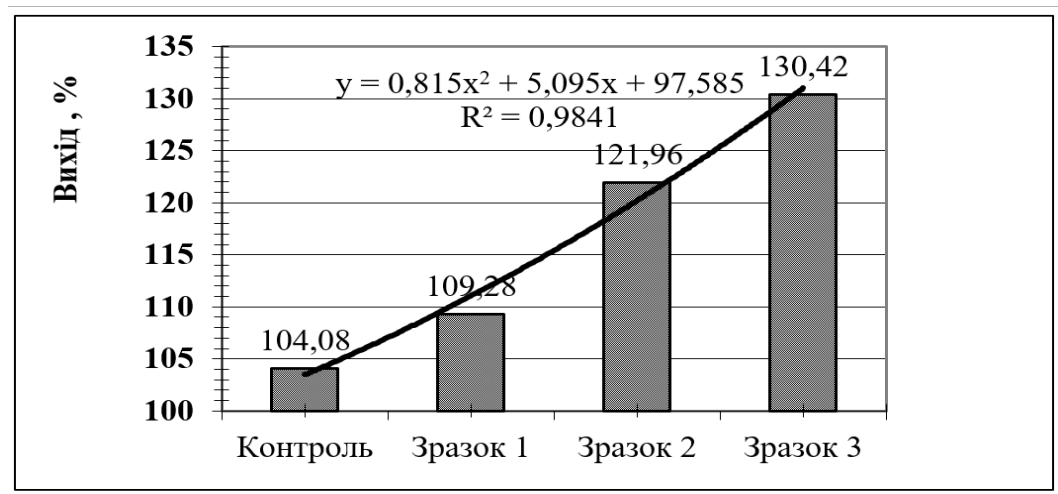

Рис. 5. Вплив пюре топінамбуру на вихід готових виробів.

Зі збільшенням частки пюре топінамбуру в рецептурі виробу вихід готового продукту зростає на $5,20 \ldots 26,34 \%$, що пов'язано 3 наявністю пектинових речовин у складі пюре, які зв'язують вологу, незважаючи на зменшення кількості клейковини борошна.
Аналіз фізико-хімічних показників (табл. 3) підтвердив, що зі зростанням кількості пюре вологість готового виробу зросла на 1,6...9,0 \%, титрована кислотність збільшилася на $0,8 \ldots 1,2{ }^{\circ} \mathrm{H}$, а пористість зменшилася на $1,93 \ldots 3,93 \%$.

\section{Таблиця 3}

Фізико-хімічні показники булочних виробів

\begin{tabular}{|c|c|c|c|c|}
\hline Назва показника & Контроль & Зразок 1 & Зразок 2 & Зразок 3 \\
\hline Вологість, \% & 29,00 & 30,60 & 35,00 & 38,00 \\
\hline Кислотність, ${ }^{\circ} \mathrm{H}$ & 2,00 & 2,00 & 2,80 & 3,20 \\
\hline Пористість, \% & 60,74 & 58,81 & 57,19 & 56,81 \\
\hline
\end{tabular}

\section{Таблиця 4}

Структурно-механічні показники булочних виробів

\begin{tabular}{lcccc}
\hline \multicolumn{1}{c}{ Назва показника } & Контроль & Зразок 1 & Зразок 2 & 3разок 3 \\
\hline Висота готового виробу, мм & 4,55 & 4,10 & 4,08 & 3,85 \\
Діаметр готового виробу, мм & 7,10 & 7,61 & 7,65 & 7,80 \\
Формостійкість & 0,64 & 0,54 & 0,53 & 0,49 \\
Питомий об'єм, г/см ${ }^{3}$ & 0,58 & 0,59 & 0,60 & 0,62 \\
\hline
\end{tabular}

Більш суттєво пюре топінамбуру вплинуло на структурно-механічні показники зразків. Зі збільшенням кількості пюре зросла розпливчастість дослідних зразків, погіршилася формостійкість виробів (табл. 4)

Дослідження основних показників якості експериментальних зразків підтверджують, що за комплексом показників, оптимальним є зразок $310 \%$ пюре топінамбуру, що дає можливість рекомендувати його для виробництва здобного булочного виробу підвищеної біологічної цінності.

\section{Висновки}

Проведені дослідження визначили перспективність використання пюре 3 топінамбуру в технології борошняних дріжджових виробів з метою підвищення їх структурно-механічних властивостей, скорочення тривалості бродіння та поліпшення органолептичних показників якості. Використання пюре 3 топінамбуру дозволить удосконалити технологію та розширити асортимент борошняних виробів із дріжджового тіста.

Перспективи подальших досліджень. Подальші дослідження спрямовоні на проведення досліджень пов'язаних із зменшенням вмісту цукру в рецептурі борошняних виробів з додаванням пюре топінамбуру та його впливом на тривалість зберігання готових виробів.

\section{References}

Ahmed, W., \& Rashid, S. (2019). Functional and therapeutic potential of inulin: A comprehensive review. Critical reviews in food science and nutrition, 59(1), 1-13. doi: 10.1080/10408398.2017.1355775.

Apolinário, A. C., de Lima Damasceno, B. P. G., \& da Silva, J. A. (2014). Inulin-type fructans: A review on different aspects of biochemical and pharmaceutical technology. Carbohydrate Polymers, 101, 368-378. doi: 10.1016/j.carbpol.2013.09.081.

Bortnichuk, O. V., Gavrysh, A. V., Njemirich, O. V., \& Docenko, V. F. (2015). Innovacijni pidhody V tehnologii' hlibobulochnyh vyrobiv z suhoju molochnoju syrovatkoju. Harchova nauka ta tehnologija, 9(2), 97-102. doi: 10.15673/20738684.31/2015.44282 (in Ukrainian).

Dorohovych, A. N., Dorohovych, V. V., \& Lazorenko, N. P. (2011). Saharozameniteli novogo pokolenija nizkoj kalorijnosti i glikemichnosti. Produkty \& ingredienty, 6(8), 46-48. URL: http://dspace.nuft.edu.ua/jspui/ 
bitstream/123456789/2307/1/sweetener_diabetes.pdf (in Russian).

Drobot, V. I. (2011). Pogovorymo shhe raz pro harchovi dobavky ta i'h funkcional'nu rol' $\mathrm{v}$ tehnologichnomu procesi. Hlibopekars'ka i kondyters'ka promyslovist' Ukrai'ny, 5(78), 8-10. URL: http://dspace.nuft.edu.ua/ bitstream/123456789/1790/1/dvipshrphdtifrutp.pdf (in Ukrainian).

Homych, G. P., Levchenko, Ju. V., \& Olijnyk, N. V. (2016). Rozrobka tehnologii' solodkyh sousiv Z vykorystannjam topinamburu ta henomelesu. Naukovi praci ONAHT, Odesa, 28-33. URL: https://www. sciworks.onaft.edu.ua/uk/site/article-view/181 (in Ukrainian).

Korkach, G. V., Lebedenko, T. Je., \& Sokolova, N. Ju. (2009). Vplyv poroshku topinambura na jakist' hlibobulochnyh vyrobiv. Naukovi praci Odes'koi' nacional'noi' akademii' harchovyh tehnologij, 36(1), 137-140. URL: http://nbuv.gov.ua/UJRN/ Np_2009_36(1)_ 41 (in Ukrainian).

Liu, J., Willför, S., \& Xu, C. (2015). A review of bioactive plant polysaccharides: Biological activities, functionalization, and biomedical applications.
Bioactive Carbohydrates and Dietary Fibre, 5(1), 3161 doi: 10.1016/j.bcdf.2014.12.001.

Pahoms'ka, O. V. (2019). Naukovyj pidhid do stvorennja hlibobulochnyh vyrobiv funkcional'nogo pryznachennja. Naukovi praci Nacional'nogo universytetu harchovyh tehnologij, 25(2), 276-283. doi: 10.24263/2225-2924-2019-25-2-30 (in Ukrainian).

Rak, S. O. (2019). Neinfekcijna epidemija cukrovogo diabetu. Medsestrynstvo, 3, 42-44. doi: 10.11603/2411-1597.2019.3.10682 (in Ukrainian).

Stankevych, G. M., Bilen'ka, I. R., \& Bulansha, N. A. (2011). Optymizacija receptur sokiv ta past na osnovi fermentovanogo topinambura. Harchova nauka i tehnologija, 4, 86-90. URL: http://nbuv.gov.ua/UJRN/ Khnit_2011_4_32 (in Ukrainian).

Vlasenko, V. V., \& Kryvoruk, V. M. (2017). Vplyv inulinu $\mathrm{z}$ topinamburu na jakist' boroshnjanyh kulinarnyh vyrobiv. Naukovyj visnyk L'vivs'kogo nacional'nogo universytetu veterynarnoi' medycyny ta biotehnologij imeni S. Z. G'zhyc'kogo. Serija: Harchovi tehnologii', 19(80), 135-139. doi: $10.15421 /$ nvlvet8028 (in Ukrainian). 